\title{
Antimicrobial Ellagitannin of Punica granatum Fruits
}

\author{
Thelma de B. Machado ${ }^{a}$, Ivana C. R. Leal ${ }^{a}$, Ana Claudia F. Amaral ${ }^{b}$, Kátia R. N. dos Santos ${ }^{c}$, \\ Marlei G. da Silva ${ }^{c}$ and Ricardo M. Kuster ${ }^{*, a}$
}

${ }^{a}$ Núcleo de Pesquisas de Produtos Naturais, Bloco H, Centro de Ciências da Saúde, Ilha do Fundão, Universidade
Federal do Rio de Janeiro, 21921-590 Rio de Janeiro - RJ, Brazil

${ }^{b}$ Laboratório de Química de Produtos Naturais e Central Analítica, Far-Manguinhos - FIOCRUZ, Rio de Janeiro - RJ, Brazil

${ }^{c}$ Instituto de Microbiologia Prof. Paulo de Góes, Bloco J, Centro de Ciências da Saúde, Ilha do Fundão, Universidade Federal do Rio de Janeiro, 21921-590 Rio de Janeiro - RJ, Brazil

\begin{abstract}
O fracionamento do extrato acetato de etila de frutos de Punica granatum, guiado por ensaios antimicrobianos frente a colônias de Staphylococcus aureus resistentes à meticilina, conduziu ao isolamento e à determinação estrutural do tanino elágico punicalagina. A identificação da substância foi realizada por CLAE/UV e RMN de ${ }^{1} \mathrm{H}$. Os ensaios antimicrobianos foram realizados pelo método de difusão em discos de papel. A concentração mínima inibitória das substâncias foi determinada pelo método de diluição em agar padronizada pelo NCCLS (National Committee for Clinical Laboratory Standards).
\end{abstract}

The ethyl acetate extract of Punica granatum fruits was fractionated by chromatographic techniques to afford the ellagitannin punicalagin. The substance was found to be active against methicillin-resistant Staphylococcus aureus strains and was identified by HPLC/UV and ${ }^{1} \mathrm{HNMR}$. The antibacterial assays which guided the isolation of the tannin were conducted using the disc diffusion method. Minimum inhibitory concentration (MIC) was determined by the dilution method according to NCCLS (National Committee for Clinical Laboratory Standards) procedure.

Keywords: Punica granatum, punicalagin, antimicrobial activity

\section{Introduction}

As part of our effort to identify the substances responsible for the pharmacological activities attributed to plants utilized in Brazil in popular medicine we have studied the epicarp of pomegranate fruits to identify the components with antimicrobial activity. Punica granatum Linn. (Punicaceae) is a shrub or small tree native to Asia ${ }^{1}$ where its several parts have been used as an astringent, haemostatic, as a remedy for diabetes, as an anthelmintic specifically against tapeworms and for diarrhoea and dysentery. ${ }^{2}$ In Brazil the fruits are known as "romã" and are used for the treatment of throat infections, coughs and fever. There are several commercial phytopreparations in Brazil containing extracts from pomegranate. For the validation of such products it is necessary to define chemical markers, substances that when present in the preparations attest their quality. ${ }^{3}$ Although many reports

* e-mail: kuster@nppn.ufrj.br

Article dedicated to Prof. Benjamin Gilbert for his $70^{\text {th }}$ birthday on the antimicrobial activity of pomegranate exist in the literature, none of them relates such activity with its chemical composition. We describe here for the first time the isolation and identification of the tannin responsible for the activity against a bacterium of medical importance (Staphylococcus aureus). Interest in plants with antimicrobial properties have been revived due to current problems associated with the use of antibiotics. With the increasing prevalence of methicillinresistant Staphylococcus aureus (MRSA) strains as pathogens in both hospital and the community, the investigation of plant extracts active against this organism provides an example of prospecting for new compounds which may be effective against infections currently difficult to treat. ${ }^{4}$

\section{Experimental}

\section{General experiments procedures}

All reagents were of analytical grade. The NMR spectrum of the compound was taken on a Varian-Gemini 
$200\left({ }^{1} \mathrm{H}\right.$ : $200 \mathrm{MHZ}$ spectrometer). Column chromatography was performed using Sephadex LH-20 (Pharmacia) and XAD-16 resin (Sigma). Thin layer chromatography was performed on cellulose plates (Merck), HPLC/UV on a Shimadzu instrument equipped with a diode array detector and RP-18 column ( $5 \mu \mathrm{m}, 20$ X $5 \mathrm{~mm}$, Merck) and preparative HPLC on a Shimadzu instrument equipped with UV detector and RP-18 column $(10 \mu \mathrm{m}, 25$ X $2 \mathrm{~cm})$. Antibacterial assays were performed on Mueller Hinton agar medium (Oxoid).

\section{Extraction and isolation of the constituents}

Fresh fruit pericarp (240 g) was exhaustively extracted with EtOH. The dried ethanolic extract was suspended in water and successively partitioned with hexane, chloroform, ethyl acetate and butanol. The most active fraction on bioassay (ethyl acetate) was chromatographed on a XAD-16 column using a water - methanol gradient. The active fraction eluted from the column with $\mathrm{H}_{2} \mathrm{O}: \mathrm{MeOH}$ (1:1) was submitted to chromatography on a Sephadex LH-20 column using a gradient $\mathrm{H}_{2} \mathrm{O}: \mathrm{MeOH}$ and the active fraction was purified on a preparative HPLC column to afford the active compound punicalagin and the inactive ones, ellagic acid and punicalin.

\section{Bacterial strains}

Brazilian prevalent clone methicillin-resistant Staphylococcus aureus strains (6 isolates - Table 1) were obtained from hospitalized patients in two Brazilian hospitals (Hospital Universitário Clementino Fraga Filho - RJ and Hospital de Clínicas da Universidade Federal de Uberlândia - MG) and identified at the Institute of Microbiology, Federal University of Rio de Janeiro. ${ }^{5}$ Furthermore, as a comparison parameter, 10 MRSA strains from other clones were tested, as well as 8 MSSA (methicillin-sensitive $S$. aureus) and 2 reference strains [ $S$. aureus ATCC 29213 (MSSA) and ATCC 33591 (MRSA)].

\section{Assay for antibacterial testing}

\section{Disc diffusion method ${ }^{6}$}

Petriplates containing $20 \mathrm{~mL}$ of Mueller Hinton agar medium were seeded with a $24 \mathrm{~h}$ old culture of the bacterial strains. The extracts, fractions and pure compounds were tested in concentration of 25 or $50 \mathrm{mg}$ $\mathrm{mL}^{-1}$, applying $10 \mu \mathrm{L}$ of each sample to sterile filter paper discs ( $5 \mathrm{~mm}$ in diameter) and placed on the surface of the medium. The inoculum size was adjusted so as to deliver a final inoculum of approximately $10^{8}$ colony-forming units $(\mathrm{CFU}) / \mathrm{mL} .{ }^{7}$ Incubation was made at $37{ }^{\circ} \mathrm{C}$ for $24 \mathrm{~h}$. The assessment of antibacterial activity was based on the measurement of diameter of the inhibition zone formed around the disc.

\section{Dilution method}

The minimum inhibitory concentration (MIC) was determined by dilution according to NCCLS. ${ }^{8}$ Mueller Hinton agar is prepared and sterilized in the usual fashion

Table 1. Susceptibility to antimicrobial agents of Brazilian prevalent clone A methicilin-resistant Staphylococcus aureus strains and antimicrobial activity of punicalagin anomers

\begin{tabular}{|c|c|c|}
\hline $\begin{array}{c}\text { PFGE }^{\mathrm{a}} \text { subtypes of } \\
\text { Staphylococcus } \\
\text { aureus }\end{array}$ & Antibiotic resistance pattern ${ }^{\mathrm{b}}$ & $\begin{array}{l}\text { Antimicrobial activity } \\
\text { of punicalagin anomers }\end{array}$ \\
\hline $\mathrm{A}_{4}$ & $\begin{array}{l}\text { OXA; IMI; CF; PN; AP; EI; TT; SFT; GN; CO; CIP; } \\
\text { KA; AM; CLI; CRO; CFO; MUP }\end{array}$ & $61.5 \mu \mathrm{g} / \mathrm{mL}$ \\
\hline $\mathrm{A}_{3}$ & $\begin{array}{l}\text { OXA; IMI; CF; PN; AP; EI; TT; SFT; GN; RIF CIP; } \\
\text { KA; AM; CLI; CRO; CFO }\end{array}$ & $61.5 \mu \mathrm{g} / \mathrm{mL}$ \\
\hline $\mathrm{A}_{2}$ & $\begin{array}{l}\text { OXA; IMI; CF; PN; AP; EI; TT; SFT; GN; CO; CIP; } \\
\text { KA; AM; CLI; CRO; CFO }\end{array}$ & $61.5 \mu \mathrm{g} / \mathrm{mL}$ \\
\hline $\mathrm{A}_{5}$ & $\begin{array}{l}\text { OXA; IMI; CF; PN; AP; EI; TT; SFT; GN; CO; CIP; } \\
\text { KA; AM; CLI; CRO; CFO }\end{array}$ & $61.5 \mu \mathrm{g} / \mathrm{mL}$ \\
\hline $\mathrm{A}_{2}$ & $\begin{array}{l}\text { OXA; IMI; CF; PN; AP; EI; TT; SFT; GN; CO; CIP; } \\
\text { KA; AM; CLI; CRO; CFO; MUP }\end{array}$ & $61.5 \mu \mathrm{g} / \mathrm{mL}$ \\
\hline $\mathrm{A}_{1}$ & $\begin{array}{l}\text { OXA; IMI; CF; PN; AP; EI; TT; SFT; GN; RIF; CO; } \\
\text { CIP; KA; AM; CLI; CRO; CFO; }\end{array}$ & $61.5 \mu \mathrm{g} / \mathrm{mL}$ \\
\hline
\end{tabular}




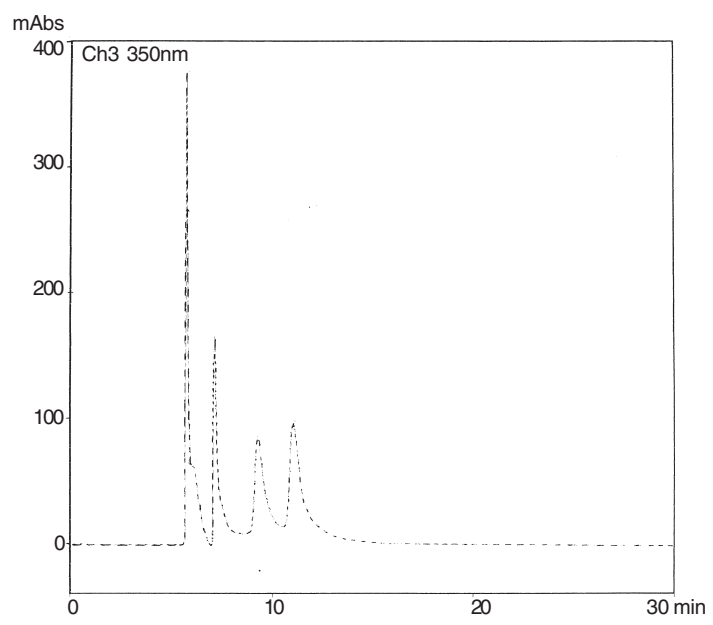

$1 \mathrm{~A}$
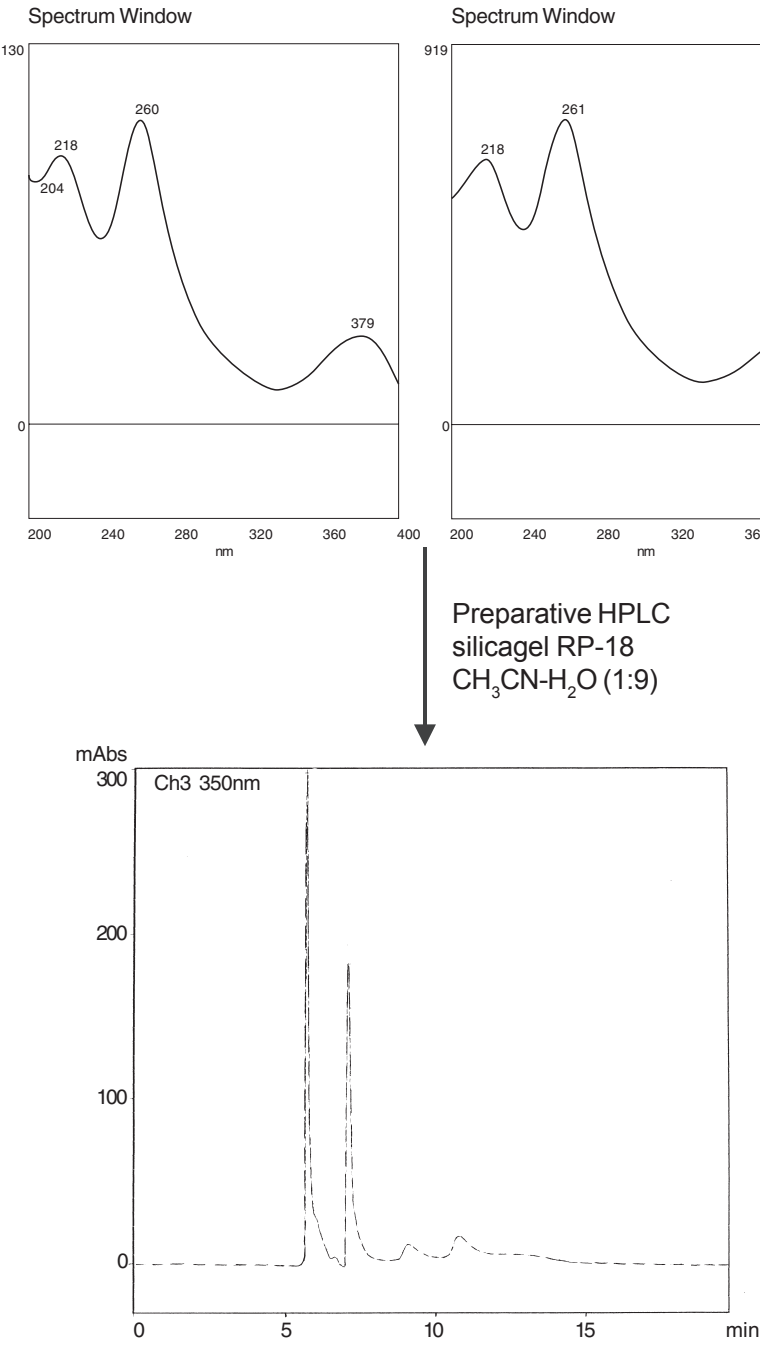

Punicalagin $\alpha$ and $\beta$ (RT $=5.66$ and $7.08 \mathrm{~min}$ )
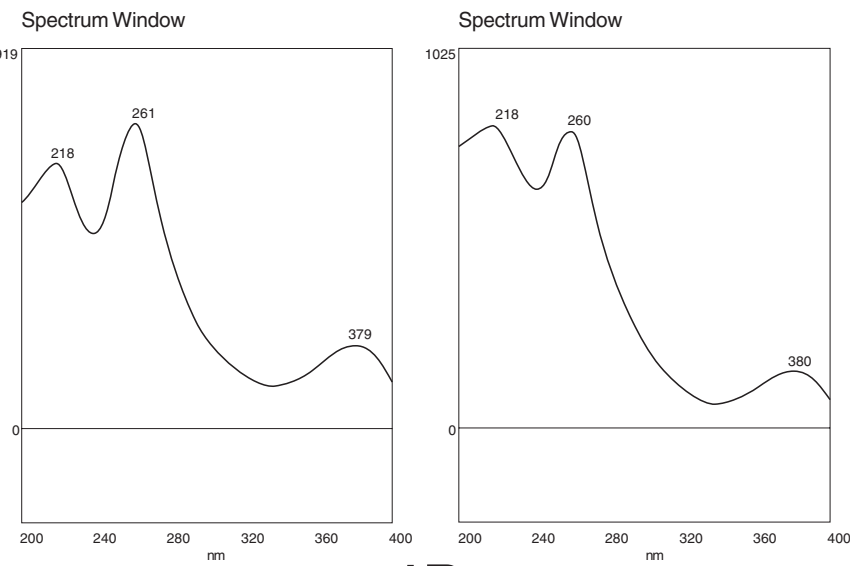

1B
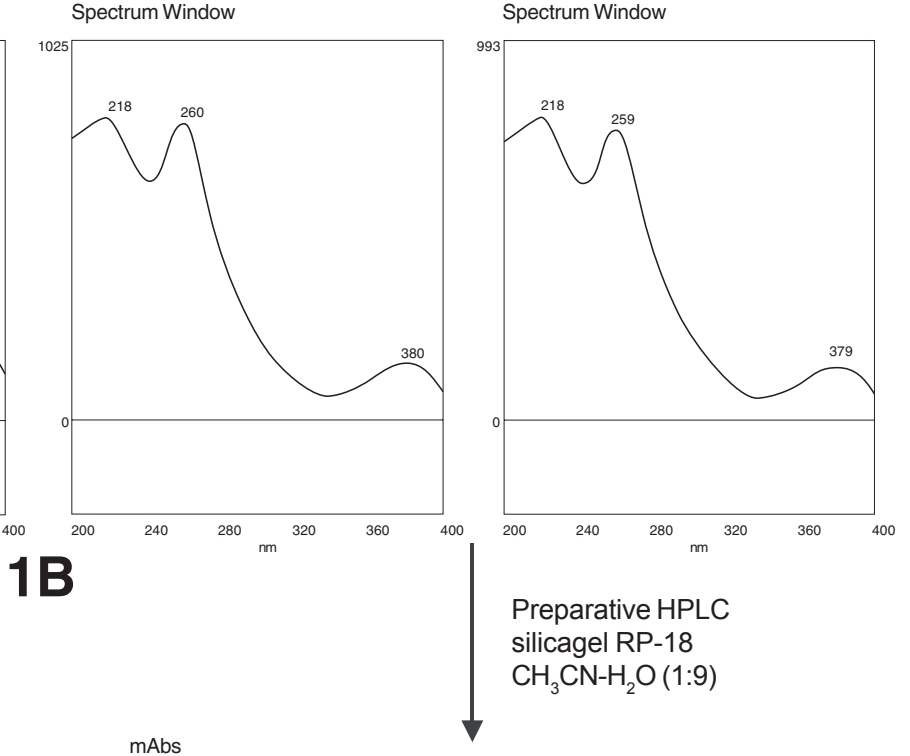

Preparative HPLC

silicagel RP-18

$\mathrm{CH}_{3} \mathrm{CN}-\mathrm{H}_{2} \mathrm{O}(1: 9)$

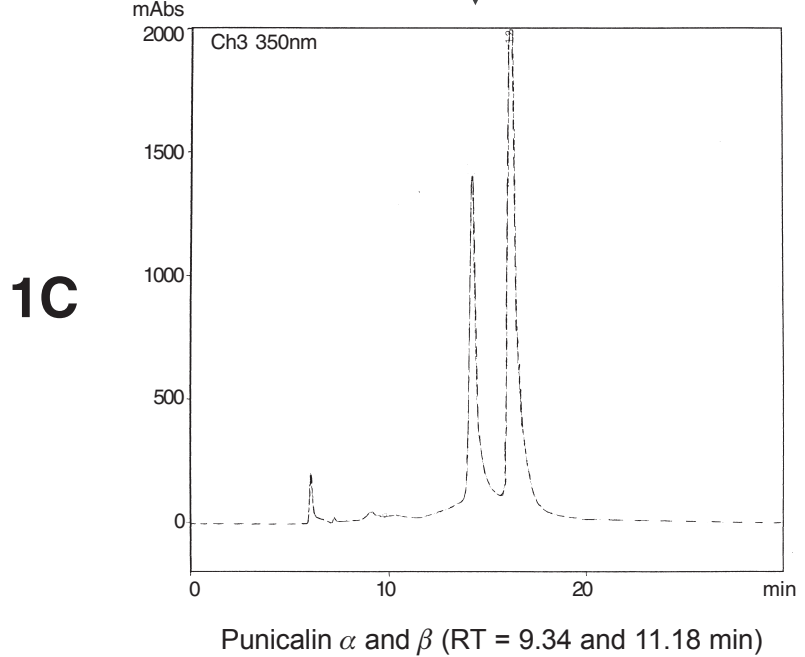

Figure 1. Characteristic HPLC chromatograms and UV spectra of the anomers punicalin and punicalagin (silicagel $\mathrm{RP}^{-18}, \mathrm{KH}_{2} \mathrm{PO}_{4} 0.01 \mathrm{~mol} \mathrm{~L}^{-1}+$ $\left.\mathrm{H}_{3} \mathrm{PO}_{4} 0.01 \mathrm{~mol} \mathrm{~L}^{-1}+\mathrm{CH}_{3} \mathrm{CN}-4: 4: 2\right)$. 1A - Analytical chromatogram of the mixture. 1B - UV spectra of each compound. 1C - Analytical chromatogram after the preparative HPLC separation. 
by autoclaving. Before solidification, $20 \mathrm{~mL}$ of agar medium is added to each of the Petri dishes containing the samples and the Petri dishes are swirled carefully until the agar begins to set. Final concentration from 250 to $0,97 \mu \mathrm{g} \mathrm{mL}^{-1}$ were used for each plant sample. The bacterial inoculum size was adjusted so as to deliver a final inoculum of approximately $10^{4}$ colony-forming units $\left(\mathrm{CFU} / \mathrm{mL}^{8}\right.$ and was added to the medium using a Steers replicator.

\section{Results and Discussion}

The active fraction when analyzed by TLC on cellulose plates $\left(\mathrm{H}_{2} \mathrm{O}: \mathrm{CH}_{3} \mathrm{COOH}, 4: 1\right)$ showed initially the presence of two orange colored spots with $\mathrm{NaNO}_{2}$ reagent, turning purple after some minutes. This is a characteristic reaction for ellagitannins. ${ }^{9}$ However, these two substances show up as four when analyzed by analytical HPLC/UV (Figure1A). Each one of the four peaks was obtained by preparative HPLC $\left(\mathrm{H}_{2} \mathrm{O}: \mathrm{CH}_{3} \mathrm{CN}, 9: 1\right)$ and after liophilization was reanalyzed by analytical HPLC/UV. Figure $1 \mathrm{C}$ shows the presence of two substances for each peak. This is in fact a characteristic phenomenon of hydrolysable tannins with an unsubstituted anomeric hydroxyl group. ${ }^{10}$ The substances were identified as punicalin $\alpha \mathbf{1}$ and punicalin $\beta \mathbf{2}$, punicalagin $\alpha \mathbf{3}$ and punicalagin $\beta \mathbf{4}$, the major ellagitannins from the pomegranate. ${ }^{11}$ Figure $1 \mathrm{~B}$ shows the UV spectra of these substances $\left(\lambda_{\max }=218,260\right.$ and $\left.379 \mathrm{~nm}\right)$. These values are characteristic of a gallagyl cromophore ${ }^{12}$ conferring to the compounds a bright yellow colour. Acid hydrolysis of punicalin afforded gallagyldilactone (identified by HPLC/UV, RT $3.2 \mathrm{~min}$ ) and glucose (identified by co-chromatography on silica gel plates). Acid hydrolysis of punicalagin afforded gallagyldilactone, ellagic acid (HPLC/UV, $3.2 \mathrm{~min}$ and $4.9 \mathrm{~min}$ ) and glucose.

Punicalagin (3 and 4)- yellow amorphous powder (320 mg), $[\alpha]_{\mathrm{D}}{ }^{20}-123.43(c=1.28, \mathrm{MeOH}) ;{ }^{1} \mathrm{H}-\mathrm{NMR}$ (CD $\mathrm{OD}) \delta 2.15$ (1H, m, H-5), 3.15 - 3.45 (1H, m, H-4), $3.98-4.17$ (1H, m, H-6), 6.42, 6.55, 6.65, 6.82 (each H, s, aromatic-H). ${ }^{13}$

The antibacterial activity for punicalagin $(250 \mu \mathrm{g}$ disc diffusion method - Figure 4) afforded a clear inhibition zone of $20 \mathrm{~mm}$ for all bacteria tested. The minimum inhibitory concentration was established as $61.5 \mu \mathrm{g} \mathrm{mL}^{-1}$ (Table 1). It is noteworthy that Burapadaja and Bunchoo, ${ }^{13}$ in a phytochemical study of Terminalia citrina, isolated punicalagin and assayed it against several bacterial

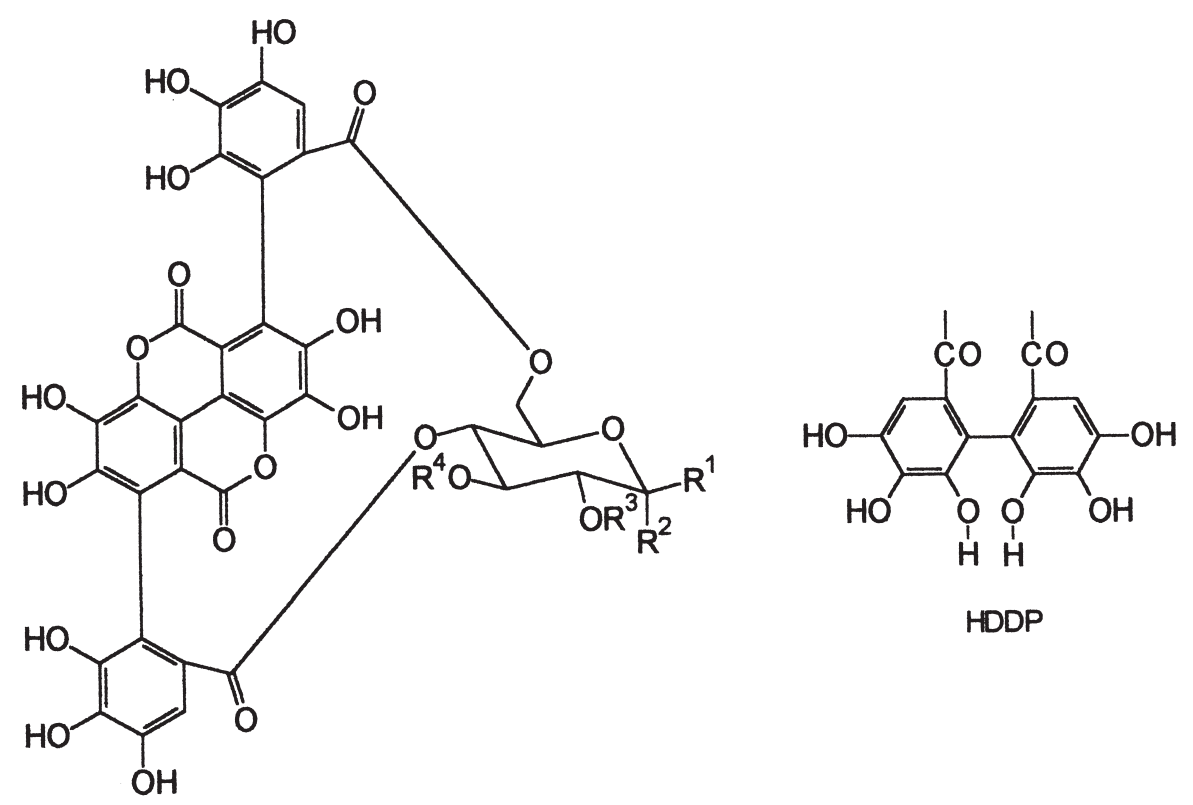

$$
\begin{aligned}
& 1 R^{1}=H ; \quad R^{2}=O H ; \quad R^{3}=R^{4}=H \\
& 2 R^{1}=O H ; \quad R^{2}=H ; \quad R^{3}=R^{4}=H \\
& 3 R^{1}=H ; \quad R^{2}=O H ; \quad R^{3}: R^{4}=H D D P \\
& 4 R^{1}=O H ; \quad R^{2}=H ; \quad R^{3} ; R^{4}=H D D P
\end{aligned}
$$

Figure 2. Ellagitannins from the pericarp of Punica granatum. 
colonies. For a methicillin-resistant $S$. aureus colony, they found a MIC value of $768 \mu \mathrm{g} \mathrm{mL}^{-1}$.

\section{Conclusion}

Our results show that the ellagitannin punicalagin is the substance responsible for the antimicrobial activity of the pomegranate. Furthermore, this compound presented an activity 10 fold higher than the one found by Burapadaja and Bunchoo. ${ }^{13}$ For the standardization of phytopharmaceuticals it could be the chemical marker of choice.

\section{Acknowledgements}

The authors thank Prof. W.B. Mors for his assistance and CNPq for a scholarship (T.B.M.)

\section{References}

1. Jafri, M.A.; Aslam, M.; Javed, K.; Singh, S.; J. Ethnopharmacol. 2000, 70, 309.

2. Das, A.K.; Mandal, S.C.; Banerjee, S.K.; Sinha, S.; Das, J.; Saha, B.P.; Pal, M.; J. Ethnopharmacol. 1999, 68, 205.

3. Gunther, B.; Wagner, H.; Phytomedicine 1996, 3, 59.
4. Cowan, M.M.; Clin. Microbiol. Rev. 1999, 12, 564.

5. Santos, K.R.N.; Teixeira, L.M.; Leal, G.S.; Fonseca, L.S.; Filho, P.P.G.; J. Med. Microbiol. 1999, 48, 17.

6. Rios, J.L.; Recio, M.C.; Villar, A.; J. Ethnopharmacol. 1988, 23, 127.

7. National Committee for Clinical Laboratory Standards 1993, Performance standards for antimicrobial disk susceptibility test - fifth edition - Approved Standards: M2-A5. NCCLS, Villa Nova, P.A.

8. National Committee for Clinical Laboratory Standards 1993, Methods for dilution antimicrobial susceptibility tests for bacteria that grow aerobically - third edition - Approved Standards: M7-A3. NCCLS, Villa Nova, P.A.

9. Bate-Smith, E.C.; Phytochemistry 1972, 11, 1153.

10. Hatano, T.; Yoshida, T.; Shingu, T.; Okuda, T.; Chem. Pharm. Bull. 1988, 36, 2925.

11. Tanaka, T.; Nonaka, G.I.; Nishioka, I.; Chem. Pharm. Bull. 1986, 34, 650 .

12. Doig, A.J.; Williams, D.H.; Oelrichs, P.B.; Baczynskyj, L.; J. Chem. Soc., Perkin Trans. 1, 1990, 2317.

13. Burapadaja, S.; Bunchoo, A.; Planta Med., 1995, 61, 365.

Received: May 6, 2002

Published on the web: August 21, 2002 